Dhaka Univ. J. Biol. Sci. 28(1): 83-91, 2019 (January)

\title{
REASSESSMENT OF THE THREATENED STATUS OF IUCN RED LISTED INDIAN RIVER SHAD GUDUSIA CHAPRA (HAMILTON, 1822) FROM BANGLADESH
}

\author{
Gouri Mondal, Samapti Saha, Md. Monirul Islam*, Goutam Kumar Kundu, \\ Bijoya Paul, Md. Foijul Hasan ${ }^{1}$ and Md. Ghulam Mustafa \\ Department of Fisheries, University of Dhaka, Dhaka-1000, Bangladesh.
}

Key words: Gudusia chapra, Biodiversity, Conservation, Bangladesh

\begin{abstract}
The Indian river shad, Gudusia chapra, locally known as chapila fish is rich in nutritive values and important to artisanal and subsistence fisheries in Bangladesh. The conservation status of this species is of particular interest due to its recent decline in rivers. To assess the current status of this species in Bangladesh, we recorded its abundance at seven sites in the Padma, the Meghna and the Tetulia rivers during pre-monsoon, monsoon and post-monsoon seasons. In this study, G. chapra was consistently recorded in the study area and there was no significant temporal or spatial variation in its abundance. The observed mean length and weight of the species were similar to those recorded in earlier studies. Currently, G. chapra is listed as vulnerable species in the IUCN Red List of Threatened Species in Bangladesh. Although the primary known habitat of this species is river, IUCN assessment was based on production from beel and Kaptai Lake habitats. In this study, consistent occurrence and availability of the species across spatial and temporal scales in rivers suggest the necessity to reassess the conservation status of G. chapra in the country.
\end{abstract}

\section{Introduction}

In Bangladesh, fish production has increased in river ${ }^{(1)}$, while beel and floodplain fish production is experiencing a decreasing trend ${ }^{(1)}$. However, in recent years, the riverine ecosystems in the country have changed considerably due to human intervention, intense tourism, pollution and climate change induced destruction of migratory routes, altered wild ecosystems and deterioration of the quality of water ${ }^{(2-5)}$. These changes impact on the growth, physiology, gonadal, and reproductive pattern of fish, which have ultimate effect on biodiversity loss in natural habitats. Several fish species are already in the face of extinction and many other species are in risk of extinction in near future ${ }^{(5)}$. Under the circumstances, assessing the status of fish can provide crucial insights to the conservation aspects and management of overall ecosystems. The IUCN Red List of Threatened Species provides such information on various species including freshwater fish in Bangladesh $^{(5)}$. The assessment of IUCN red data lists the evaluated species under several

*Author for correspondence: <monirulislam153@yahoo.com>. ${ }^{1}$ WorldFish Bangladesh and South Asia Office, Dhaka, Bangladesh. 
categories including extinct or regionally extinct (EX), critically endangered (CR), endangered (E), vulnerable (V), near threatened (NT), least concern (LC) and data deficient (DD) species.

In Bangladesh, there are 253 freshwater fish species(5). A number of assessments have been conducted to demark the conservation status of red-listed species of haor and different rivers in Bangladesh ${ }^{(5-9)}$. The Indian river shad, Gudusia chapra (Hamilton 1822), locally known as chapila, is listed under the vulnerable category in IUCN red list(5). This small indigenous fish species is an important food fish species in Bangladesh ${ }^{(10-12)}$ and contributes to the nutrition of rural people in Bangladesh ${ }^{(13-14)}$. It is an important species for research as different studies showed conflicting data about its availability in different water bodies ${ }^{(6-9,15)}$. In his study, Patwary found that G. chapra was $30 \%$ of total production in Kaptai Lake in 2013-14. Besides, Department of Fisheries claimed in a survey in 2012 that the production of G. chapra decreased in beel by $48 \%$, whereas it increased in Kaptai Lake by $50 \%$ in 10 years.

In 2000, IUCN declared G. chapra as a not threatened species ${ }^{(16)}$. However, in 2015, it was reclassified as vulnerable based on its population trend in beel and Kaptai Lake. The fish species listed under vulnerable category has either reduced, small, restricted population or gradually confined geographic range, and therefore meets any of the criteria mentioned in $\mathrm{IUCN}^{(5)}$. The vulnerable species has high risk to extinction in the wild, which raise the necessity to study such species for conservation and other aspects(5). Rivers are the known primary habitat to G. chapra and several studies have reported the presence of $G$. chapra from various rivers ${ }^{(7-8)}$. The species is also common in the largest wetland of the North Bengal, the Chalan beel ${ }^{(17)}$. However, the 2015 IUCN assessment did not assess population in rivers and there is no study exclusively focusing on the conservation status of $G$. chapra in rivers ${ }^{(5)}$. Therefore, this study investigates the current status of G. chapra in different areas of major rivers of Bangladesh, which included the rivers Padma, Meghna and Tetuilia. The findings have been incorporated with the scant current information on this species in literature suggesting reclassify the conservation status of Gudusia chapra in Bangladesh.

\section{Materials and Methods}

The present study was conducted in three rivers in Bangladesh, namely, the Padma and the Meghna and the Tetulia Rivers to explore the present status of G. chapra. Considering the spatial variation in species composition, sampling was conducted at seven sites (Site A-G) along the riverine channel (Fig. 1). Since availability and catchability of fish species can vary considerably over seasons, sampling were conducted in three seasons, namely, pre-monsoon (June), monsoon (August) and post-monsoon (November). 


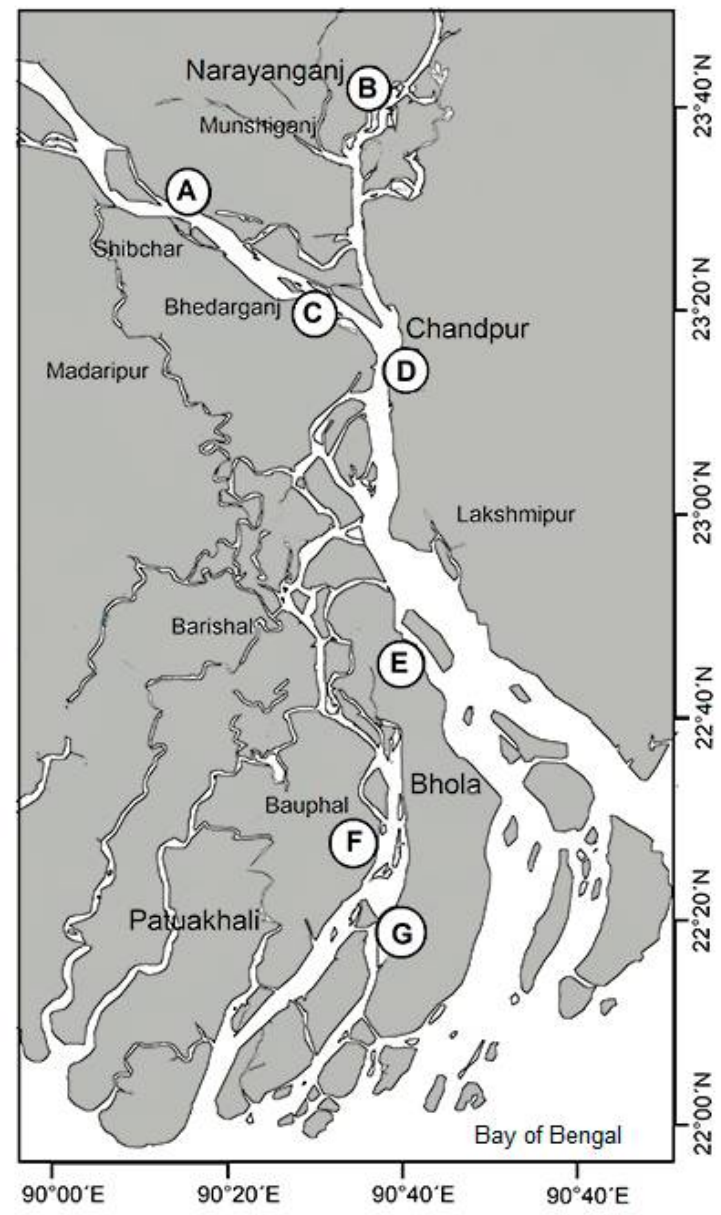

Fig. 1. Map showing location of sampling sites. $\mathrm{A}=$ Lower Padma near Mawa, $\mathrm{B}=$ Upper Meghna near Boidder Bazar, $C=$ Lower Padma near Bhedorganj, D = Lower Meghna near Bohoria market, E = Lower Meghna near Char Shibpur, F = River Tetulia near Kaliya and G = River Tetulia near Gosher Hat.

At each site, G. chapra samples were collected from the total landings using gill net, lifting net, seine net, drift net and traps. G. Chapra were identified based on the morphometric and meristic characteristics following Shafi and Quddus (1982)(19) and Rahman (2005) ${ }^{(31)}$ and the total abundance of the species in all gears were counted. $10 \%$ of the total samples were used to record the length and weight of individuals. The abundance, length and weight data of fish were tested for any spatial or seasonal differences using the Kruskal-Wallis test as the data did not satisfy the normality assumption (Shapiro-Wilk test, $\mathrm{p}>0.05$ ). Data on geographical distribution, habitat, food, population trends of $G$. chapra were collected from various research articles, Government publications and different types of books. 
Based on the findings in this study and other recent records in different natural habitats the current status of $G$. chapra were evaluated. The assessment intended to check whether G. chapra fall within the IUCN criteria for a vulnerable species as summarized in Table 1.

Table 1. Summary of assessment criteria of a species to be listed as vulnerable in Red List of Threatened Species (IUCN 2015).

\begin{tabular}{|c|c|c|}
\hline Criteria & & Indicator \\
\hline \multirow{4}{*}{$\begin{array}{l}\text { A. Reduction in } \\
\text { population size }\end{array}$} & 1. & $\begin{array}{l}\text { An observed, estimated, inferred or suspected population size } \\
\text { reduction of } 50 \% \text { over the last } 10 \text { years or three generations, } \\
\text { whichever is the longer, where the causes of the reduction are } \\
\text { clearly reversible and understood and ceased. }\end{array}$ \\
\hline & 2. & $\begin{array}{l}\text { An observed, estimated, inferred or suspected population size } \\
\text { reduction of } 30 \% \text { over the last } 10 \text { years or three generations, } \\
\text { whichever is the longer, where the reduction or its causes may } \\
\text { not have ceased or may not be understood or may not be } \\
\text { reversible. }\end{array}$ \\
\hline & 3. & $\begin{array}{l}\text { A population size reduction of } 30 \% \text { projected or suspected to be } \\
\text { met within the next } 10 \text { years or three generations, whichever is } \\
\text { the longer (up to a maximum of } 100 \text { years). }\end{array}$ \\
\hline & 4. & $\begin{array}{l}\text { projected or suspected population size reduction of } 30 \% \text { over } \\
\text { any } 10 \text { year or three generation period, whichever is longer (up } \\
\text { to a maximum of } 100 \text { years in the future), where the time period } \\
\text { must include both the past and future and where the reduction } \\
\text { or its causes may not have ceased or may not be understood or } \\
\text { may not be reversible. }\end{array}$ \\
\hline \multirow{2}{*}{ B. Geographic range } & 1. & Extent of occurrence $<20,000 \mathrm{~km}^{2}$ \\
\hline & 2. & Area of occupancy $<2,000 \mathrm{~km}^{2}$ \\
\hline C. Population size & & $\begin{array}{l}\text { Population size estimated to number fewer than } 10,000 \text { mature } \\
\text { individuals. }\end{array}$ \\
\hline D. Population & & $\begin{array}{l}\text { Population very small (number fewer than 1,000 mature } \\
\text { individuals) or restricted typically less than } 20 \mathrm{~km}^{2} \text { ). }\end{array}$ \\
\hline E. Quantitative analysis & & $\begin{array}{l}\text { Quantitative analysis showing the probability of extinction in the } \\
\text { wild is at least } 10 \% \text { within } 100 \text { years. }\end{array}$ \\
\hline
\end{tabular}




\section{Results and Discussion}

The G. chapra was found at all sampling sites during this study. The abundance was apparently variable which ranged from none to 46 in total 21 sampling operations. However, the spatial or seasonal difference in the abundance were not significant (Kruskal-Walis test, $\mathrm{p}>0.05$ ). While the highest number of individuals (46) was recorded at the upper Meghna river site during post-monsoon, there was no individuals of $G$. chapra in the total catch once in every three samples. The absence of this species in a sample was due to low total landing of all species. Therefore, the absence of this species in a sample did not indicate total absence in relevant river section. The site wise pulled abundance indicated that abundance was higher at the upstream sites at each river (sites A, B and F) (Fig. 2a). It might be due to the higher connectivity of upstream river sections with nearby freshwater habitats like floodplains and beels.
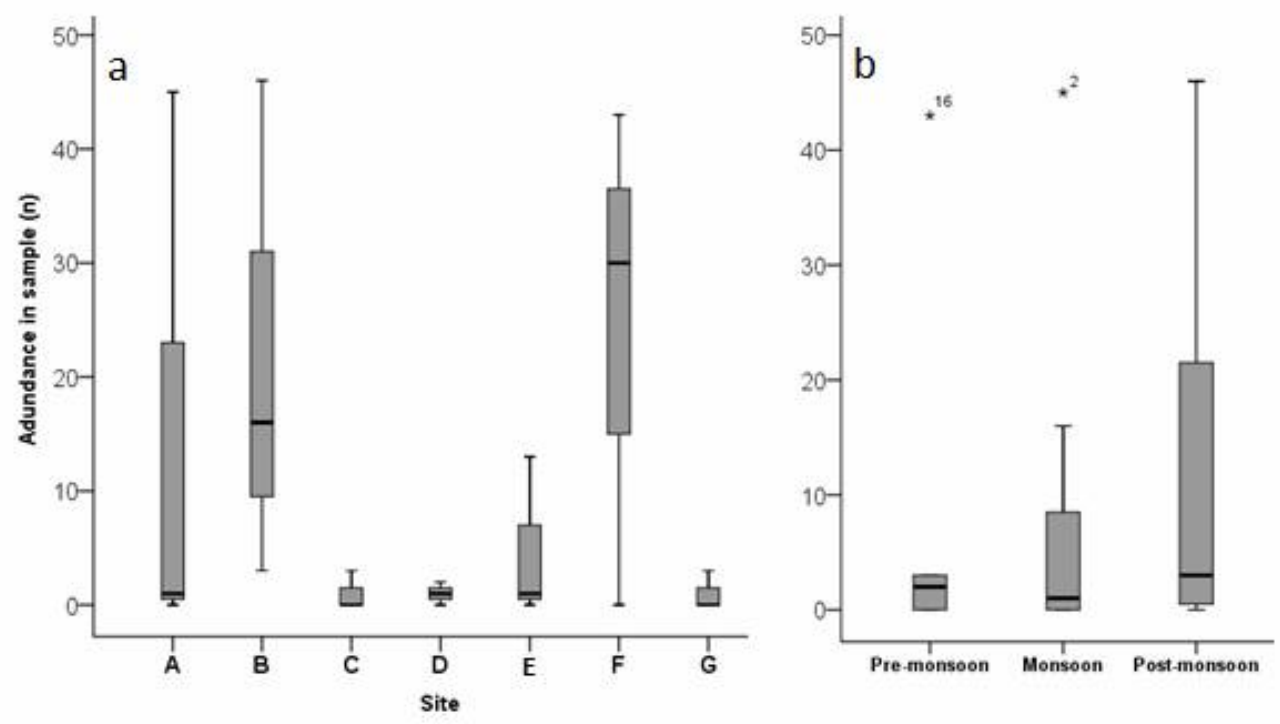

Fig. 2. Spatial (a) and seasonal (b) pattern of abundance of Gudusia chapra (Hamilton, 1822) in three rivers in Bangladesh.

In this study, the abundance of G. chapra apparently increased during post-monsoon (Fig. 2b). The seasonality of abundance depends on different environmental and ecological factors such as, water depth, connectivity to nearby habitats, abundance of food sources, etc. The above mentioned studies in various rivers reported the occurrence of G. chapra in the catch throughout the year. However, past studies suggests this species are abundant in catch from July to September ${ }^{(18-20)}$ which supports the findings of the present study. It is to be noted that the catchability of riverine fish also varies notably depending on the gears. The apparent higher abundance during post-monsoon is probably due to increased catchability related to low water depth in rivers. 
In the present study, length and weight of sampled fish ranged between 5.3 to 20.4 $\mathrm{cm}$ and 1.0 to $60.2 \mathrm{~g}$, respectively. The length-weight parameters recorded in the current study are similar to the values reported earlier in various rivers(8, 20-21).

In recent years, a number of other studies also reported occurrence of G. chapra from the Meghna ${ }^{(9,22)}$, the Padma ${ }^{(23)}$ and other rivers. This species was reported to contribute at various percentages of total catch from the Brahmaputra ${ }^{(24)}$ and Choto Jamuna(25) which are further upstream stretches than this study sites. It was also represented in the catch regularly at rivers connected to brackish waters(26-27). However, a systematic comparison of abundance in rivers over the time series was not possible due to lack of continuous data and high variability in study methods among existing studies.

As mentioned above, the IUCN assessment in 2015 took into account the population trend in beel and Kaptai Lake. Production of this species decreased by $48 \%$ in beel and increased by $50 \%$ in Kaptai Lake over 10 years ${ }^{(28)}$. Since rivers are the primary habitat to this species, it is imperative to take into account the riverine population to understand the conservation status of the species. However, the riverine catch data in various published and unpublished do not present abundance or production status of G. chapra as a single species. Although abundance of a species does not reflect true population level status with sufficient confidence, it might serve as a potential indicator to overall population status. The present study recorded the abundance of G. chapra at different sites along the $\sim 200 \mathrm{~km}$ of river channel indicating the extent and area of occurrence of the species was over the respective minimum criteria of IUCN red list assessment. Moreover, other recent studies reported continuous occurrence at both upstream and downstream rivers and across the different regions in Bangladesh. Therefore, the status of riverine sub-population of G. chapra might differ from those in Kaptai Lake or beel. This raises the necessity of a more comprehensive evaluation of conservation status of $G$. chapra in Bangladesh.

The silver coloured Indian river shad G. chapra is a Clupeidae fish with 26 to 29 scutes along the belly. Deep body and dark blotch behind gill opening are two of the main identifying characteristics, which are often followed by a series of spots along the flank. This species has been widely distributed in the natural waters of Bangladesh, India, Pakistan, Nepal, Bhutan, Sri-Lanka, Myanmar, and Afghanistan ${ }^{(18,29)}$. Although freshwater rivers, beels, ponds, ditches and inundated fields are main habitats for this species, it is frequently caught in brackish water ${ }^{(30-31)}$. However, a study reported that it is now disappearing from natural systems due to severe reductions in biodiversity ${ }^{(32)}$. In Bangladesh, G. chapra has been described as a dominant and important target species in artisanal and subsistence fisheries ${ }^{(33-34)}$. The IUCN listed this species as vulnerable based on its population trend in beel and Kaptai Lake. The species was also listed as vulnerable in India ${ }^{(35)}$. This study demonstrated the consistent abundance of G. chapra in rivers in Bangladesh through direct abundance survey and literature review. 
This study recorded abundance of G. chapra in three rivers in Bangladesh. The species was found across all the studied sites and seasons. However, there was not significant spatial or temporal difference in abundance. The results of the current study along with a number of other studies in recent past in different rivers across the country suggest that a more comprehensive assessment of the conservation status of G. chapra is necessary to reevaluate the recent status of the fish as vulnerable species in the IUCN red list of Bangladesh.

\section{References}

1. Anonymus 2016. Annual report, Department of Fisheries, Ministry of Fisheries and Livestock, Government of the People's Republic of Bangladesh.

2. Mondal G 2014. Impact of anthropogenic and natural drivers on Ganges, Brahmaputra, Meghna River fish diversity in Bangladesh. In:River for Life: Proceedings of the international symposium on river biodiversity: Ganges- Bramhaputra- Meghna system. pp. 176-183.

3. Hossain MS, L Hein, F Rip and J Dearing 2013. Integrating ecosystem services and climate change responses in coastal wetlands developments plans for Bangladesh. Mitig. Adapt. Strat. Glob. Change. doi:10.1007/s11027-013-9489-4.

4. Hossain MS, K Roy and D Datta 2014. Spatial and temporal rainfall variability of rainfall over the south west coast of Bangladesh. Climate 2(2): 28-46. doi:10.3390/cli2020028.

5. IUCN Bangladesh 2015. Red List of Bangladesh. Vol. 5. Freshwater Fishes. IUCN (International Union for Conservation of Nature), Bangladesh Country Office, Dhaka, Bangladesh, pp. xvi+360.

6. Iqbal MM, MH Kanon, MA Hossain, A Hossain, S Nasren, MJ Islam and MA Rahman 2015. Diversity of indigenous fish species in Konoskhaihaor, northeast Bangladesh. Punjab Univ. J. Zool. 30(2): 73-79.

7. Islam M, A Asif, M Samad, B Sarker, M Ahmed, A Satter and A Hossain 2017. A comparative study on fish biodiversity with conservation measures of the Bhairab river, Jessore, Bangladesh. Asian J. Med. Biol.Res. 3(3): 357-367. doi:http://dx.doi.org/10.3329/ajmbr. v3i3. 34526.

8. Hanif MA, MAB Siddik, A Nahar, MR Chaklader and Rumpa 2016. The current status of small indigenous fish species (SIS) of river Gorai, a distributary of the river Ganges, Bangladesh. J. Biodivers. Endanger. Species 4:162. doi: 10.4172/2332-2543.1000162.

9. Pramanik MMH, MM Hasan, S Bisshas, AA Hossain, and TK Biswas 2017. Fish biodiversity and their present conservation status in the Meghna River of Bangladesh. Int. J. Fish. Aquat.5(1): $446-455$.

10. MazumderMSA, MM Rahman, ATA Ahmed, M Begum and MA Hossain 2008. Proximate composition of some small indigenous fish species (SIS) in Bangladesh. Int. J. Sustain. Crop Prod. 3(3):18-23.

11. Nanna R, MM Islam and SH Thilsted 2003. Small indigenous fish species in Bangladesh: contribution to vitamin A, calcium and iron intakes. J. Nutr. 133(11): 4021S-4026S. https:// doi.org/10.1093/n/133.11.4021S. 
12. Sharma P, D Kashyap and U Goswami 2013. Preparation and storage of salted and dried products of freshwater fish, Gudusia chapra (Hamilton, 1822). Int. Qutr. J. Life Sci. 8(2): 455-458.

13. Thilsted SH 2003. The importance of small indigenous fish species for improved human nutrition in rural Bangladesh. In: Wahab MA, Thilsted SH and Hoq ME (eds), Small indigenous species of fish in Bangladesh, Technical Proceedings of BAU-ENRECA/DANIDA workshop on potentials of small indigenous species of fish (SIS) in aquaculture \& rice-field stocking for improved food \& nutrition security in Bangladesh. Bangladesh Agricultural University, Mymensingh.

14.Thilsted SH, N Roos and N Hasan 1997. The role of small indigenous fish species in food and nutrition security in Bangladesh. NAGA Newsletter. The ICLARM quarterly 20(3-4): 82-84.

15. Patwary MSA, AA Mamun, MTA Nannu, AA Rahman, and KS Nazrul 2016. Dramatic increase of Ganges river sprat (Corica soborna) and Indian river shad (Gudusia chapra): Impact on the aquatic biodiversity of kaptai lake, Bangladesh. Int. J.of Pure and Applied Zool.

16. IUCN Bangladesh 2000. Red Book of Threatened Fishes of Bangladesh. IUCN-The World Conservation Union, pp. Xii + 116 .

17. Galib SM, MA Samad, ABM Mohsin, FA Flowra and MT Alam 2009. Present status of fishes in the Chalan beel-the largest beel (wetland) of Bangladesh. Int. J. Animal and Fish. Sci. 2(3): 214218.

18. Talwar, PK and AG Jhingran 1991. Inland fishes of India and adjacent countries. Vol 2. A.A. Balkema, Rotterdam, pp. 96-97.

19. Shafi M and MMA Quddus 2001. Fisheries of Bangladesh. Kabir publications, Dhaka, Bangladesh, pp. 40-41.

20. Whitehead PJP 1985. FAO Species Catalogue. Vol. 7. Clupeoid fishes of the world (suborder Clupeioidei): An annotated and illustrated catalogue of the herrings, sardines, pilchards, sprats, shads, anchovies and wolf-herrings. FAO Fish. Synop. Rome: FAO 125(7/1): 1-303.

21. Lama B, F Ahamed, ZF Ahamd, MY Hossain and J Ohtomi 2014. Population biology of the Indian river shad, Gudusia chapra (Clupeidae) in the old Brahmaputra river, North-Eastern Bangladesh. Sains Malays. 43(11): 1645-1655.

22. Hossain MS, NG Das, S Sarker and MZ Rahaman 2012. Fish diversity and habitat relationship with environmental variables at Meghna river estuary, Bangladesh. Egypt. J. Aquat. Res. 38(3): 213-226.

23. Rahman MM, MY Hossain, F Ahamed, SB Fatematuzzhura, EM Abdallah and J Ohtomi 2012. Biodiversity in the Padma distributary of the Ganges River, northwestern Bangladesh: recommendations for conservation. World J. Zool. 7(4): 328-337.

24. Galib SM 2015. Fish fauna of the Brahmaputra River, Bangladesh: richness, threats and conservation needs. J. Fish. 3(3): 285-292.

25. Galib SM, SA Naser, ABM Mohsin, N Chaki and MFH Fahad 2013. Fish diversity of the River Choto Jamuna, Bangladesh: present status and conservation needs. Int. J. Biodivers. Conserv. 5(6): 389-395.

26. Islam MA, MM Hossain, ME Ahsan and A Nahar 2015. Status and current worries of fish diversity in the Payra river, Patuakhali, Bangladesh. Int. J. Fish. Aquat. 2(3): 160-165. 
27. Rahman MB, MZS Hoque, MM Rahman and A Nahar 2017. Exploration of fishing gear and fisheries diversity of Agunmukha River at Galachipa Upazila in Patuakhali district of Bangladesh. IJFS. 16 (1):108-126. URL: http://jifro.ir/article-1-2577-en.html.

28. FRSS 2012. Fisheries Statistical Report of Bangladesh. Fisheries Resources Survey System (FRSS), Department of Fisheries, Ministry of Fisheries and Livestock, Government of the People's Republic of Bangladesh, Bangladesh, pp. 29:12.

29. Froese R and D Pauly (Eds) 2009. Fish Base 2009. World wide Web electronic publication. Available at: http://www.fishbase.org (last accessed on 10 July 2009).

30. WORMS Editorial Board. 2017. World Register of Marine Species. Available from http://www.marinespecies.org at VLIZ. Accessed 2017-12-31. doi:10.14284/170.

31. Rahman AKA 2005. Freshwater Fishes of Bangladesh. 2nd ed., Zoological Society Bangladesh, Dhaka, Bangladesh. pp. 271-272.

32. Mijkherjee M, A Praharaj, and S Das 2002. Conservation of endangered fish stocks through artificial propagation and larval rearing technique in West Bengal, India. Aqua. Asia. 7(2): 811.

33. Craig JM, AS Halls, JJF Barr and WC Bean 2004. The Bangladesh floodplain fisheries. Fish. Res. 66: 271-286.

34. Kibria G and KKU Ahmed 2005. Diversity of selective and nonselective fishing gear and their impact on inland fisheries in Bangladesh. NAGA 28: 43-48.

35. Lakra WS and UK Sarkar 2007. Freshwater fish diversity of central India. National Bureau of Fish Genetic Resources, Lucknow.

(Manuscript received on 22 May, 2018; revised on 18 November, 2018) 